This item was submitted to Loughborough's Research Repository by the author.

Items in Figshare are protected by copyright, with all rights reserved, unless otherwise indicated.

\title{
Food and biological nature: As You Like It, Antony and Cleopatra, Pericles,
} Cymbeline and The Winter's Tale

PLEASE CITE THE PUBLISHED VERSION

PUBLISHER

Gale Cengage

VERSION

AM (Accepted Manuscript)

LICENCE

CC BY-NC-ND 4.0

\section{REPOSITORY RECORD}

Egan, Gabriel. 2019. "Food and Biological Nature: As You Like It, Antony and Cleopatra, Pericles, Cymbeline and the Winter's Tale". figshare. https://hdl.handle.net/2134/6024. 
This item was submitted to Loughborough's Institutional Repository (https://dspace.lboro.ac.uk/) by the author and is made available under the following Creative Commons Licence conditions.

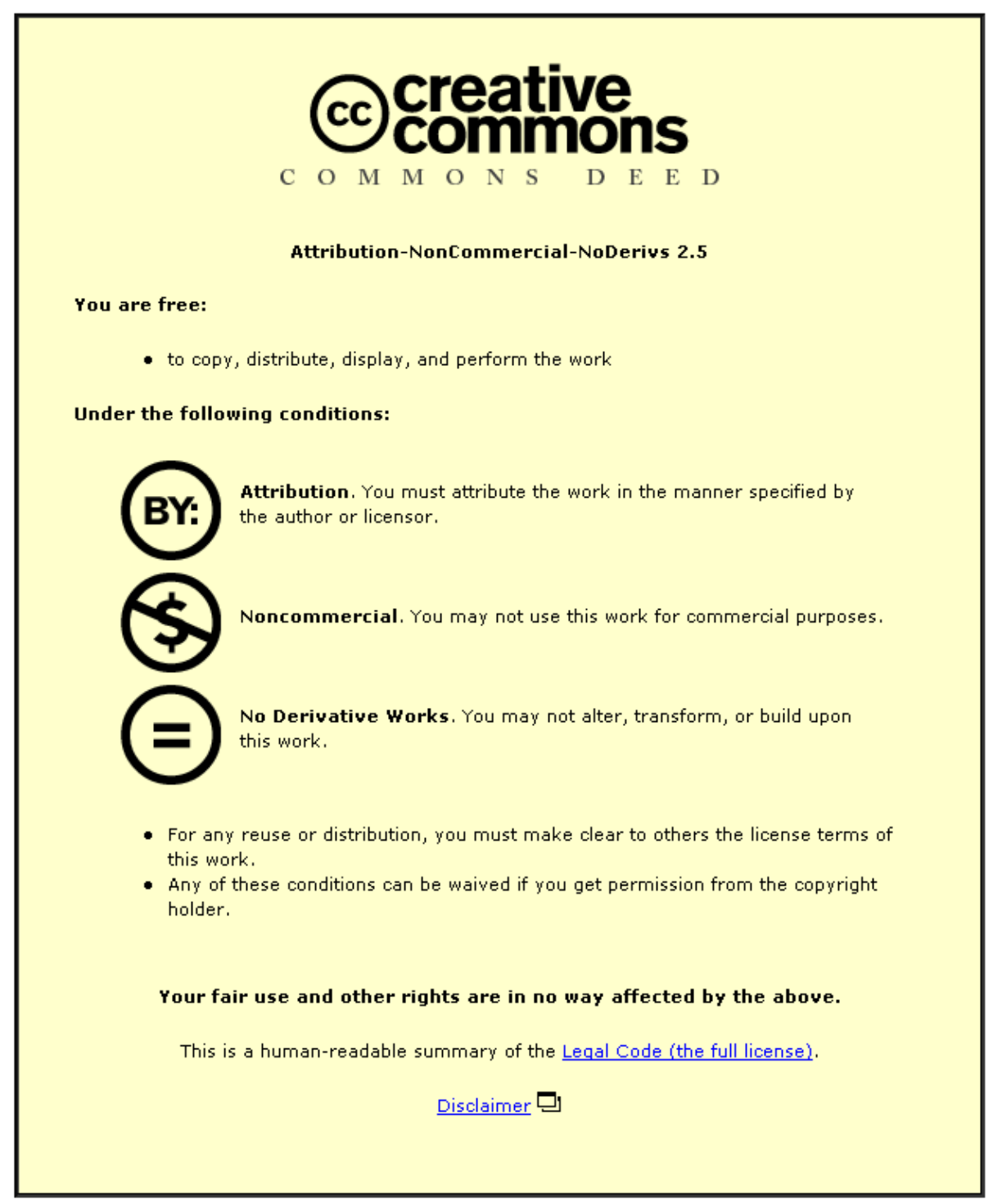

For the full text of this licence, please go to: http://creativecommons.org/licenses/by-nc-nd/2.5/ 


\section{Antony and Cleopatra}

In a number of ways, Shakespeare's Antony and Cleopatra simply does not add up. Cleopatra's last act before her suicide is to present Caesar with a false inventory of her wealth, which her treasurer (perhaps by prior arrangement) refuses to certify:

\section{CLEOPATRA}

What have I kept back?

SELEUCUS

Enough to purchase what you have made known.

(Antony and Cleopatra 5.2.143-4)

Seleucus's answer is a roundabout way of saying 'at least half', and it signals a bookkeeper's concern for the zero-sum principle of a balance-sheet. Nothing is lost, nothing gained in buying one half of one's wealth with the other. If this scene of apparent betrayal is indeed feigned to reassure Caesar that Cleopatra still imagines a future for herself (rather than intending to commit suicide), then its exploitation of an accountant's precision is a subtle device indeed, for that is just the kind of thinking she has actively resisted all her life. Cleopatra, like Timon of Athens and unlike Wilkins Micawber, ${ }^{1}$ refuses to live her life as a zero-sum game.

In that regard, Cleopatra finds Antony a kindred spirit. Asked for an accurate account of the quantity of his love, he distinguishes between the merely finite (into which category fall the small and great) and its true opposite, the infinite: "There's beggary in the love that can be reckoned" (1.1.15). Rather than quantities totalling up, losses balancing gains, the desire of Antony and Cleopatra is a paradoxical positive-feedback loop: whatever should check increase only accelerates it. Thus, in Enobarbus's description of Cleopatra's barge upon the Cydnus she personifies fire itself:

[ENOBARBUS] On each side her

Stood pretty dimpled boys, like smiling Cupids, With divers-coloured fans whose wind did seem To glow the delicate cheeks which they did cool, And what they undid did.

(Antony and Cleopatra 2.2.208-12)

We saw in Coriolanus (pp. 00-00 above) this paradox of blown air making a fire hotter or putting it out, and in Antony and Cleopatra it is but one of several such paradoxes conveying the strange nature of Cleopatra's sexual allure: "Other women cloy | The appetites they feed, but she makes hungry | Where most she satisfies" (2.2.242-4). For Enobarbus this is a matter of wonder, and even Philo's disapproving language captures the extraordinary 'less-is-more' quality of it: "[Antony's heart] is become the bellows and the fan | To cool a gipsy's lust" (1.1.9-10).

We might expect all this talk of self-reinforcing arousal to lead to 'increase' of the biologically creative kind, but the play is remarkably coy about Cleopatra's fertility and her children have only a shadowy role. Caesar's complaint about the couple's dynasty-founding ritual glances at them in passing, and only because they compounded the offence: 


\section{CAESAR}

Contemning Rome, he has done all this and more

In Alexandria. Here's the manner of 't:

I' th' market place on a tribunal silvered,

Cleopatra and himself in chairs of gold

Were publicly enthroned. At the feet sat

Caesarion, whom they call my father's son,

And all the unlawful issue that their lust

Since then hath made between them.

(Antony and Cleopatra 3.6.1-8)

In the play's final manoeuverings Caesar employs a thinly-veiled threat to persuade Cleopatra against suicide "you shall . . . put your children | To that destruction which I'll guard them from" (5.2.126-8). As Michael Neill notes, existing plays on the subject of Antony and Cleopatra made much of these children, while Shakespeare grants them only a "nominal presence" (Shakespeare 1994, 5.2.130-3n).

It is not that the play avoids the topic of fertility, only that the concern is with the peculiarly non-human and even non-biological: the strange fertility of the Nile itself. Even when Cleopatra's women ask a soothsayer to predict their sex-lives, they expect the answer to be connected to the river's fertility, as when teasing that a wet hand is like wet land: "IRAS There's a palm presages chastity, if nothing else. CHARMIAN E'en as the o'erflowing Nilus presageth famine" (1.2.42-4). The likening of human female fertility with the fertility of the Earth is, of course, a major poetic trope present in every culture and underlying the common metaphor of Mother Earth. ${ }^{2}$ Here, however, the Nile is treated as a special case within the wider trope and it is related back to the special case of Cleopatra.

The play begins and ends with the Earth Mother trope, but only to acknowledge it before a perfunctory dismissal. In the first minutes of a performance, Antony disdains his summons from Rome by contrasting coupling with Cleopatra against the merely reproductive biology of the Earth:

\section{ANTONY}

Let Rome in Tiber melt, and the wide arch Of the ranged empire fall. Here is my space. Kingdoms are clay. Our dungy earth alike Feeds beast as man. The nobleness of life Is to do thus; when such a mutual pair And such a twain can do 't. (Antony and Cleopatra 1.1.35-40)

Most editors put a stage direction for his embracing her at "to do thus", and even performed most chastely this gesture necessarily implies that whereas the Earth's reproductive principle generates food, their coupling is something better because non-reproductive. Heroic disdain of food while on military campaign is the subject of Caesar's apparently sincere eulogy in his first monologue: Antony drank "The stale of horses, and the gilded puddle", ate the "roughest berry", the "barks of trees", and even "strange flesh" that killed others (1.4.62-7). Although the sensual indulgence of the Egyptian court is amply described later, in Antony's embrace of Cleopatra he 
seems to retain a disdain for the generative principle of Earthly biology, for the way that the "dungy earth . . . feeds" people. The actor playing Cleopatra was a boy no older than 19 so we might here also catch a hint of the classical disdain for merely procreative heterosexuality evident in such stories as Aristophanes's account of the origin of love in Plato's Symposium (Plato 1871, 506-09).

In the closing minutes of a performance, Cleopatra uses the same language of disdain when describing death's quietus that: "ends all other deeds . . . shackles accidents . . . bolts up change ... sleeps and never palates more the dung, I The beggar's nurse, and Caesar's" (5.2.5-8). Just as ordinary love unites great and small in common finitude, so ordinary appetite for food unites beggar and monarch in sucking sustenance from the dungy Earth. On the other side stand the extraordinary, the infinite, death. We might also hear in this idea of palating the dungy Earth the reverse meaning: not to taste but to "make palatable" (OED palate $\underline{v}$. 2 ). Such a reversal gives Hamlet his grim joke about Polonius being at supper with the worms, "Not where he eats, but where a is eaten" (Hamlet 4.3.20), and here it suggests Cleopatra's anxiety about feeding the Earth with her dead body. Indeed, it is possible to see the final scene's repetition of the word 'worm' (9 times, against a background average of one or two instances per play) as a mantra of death, just as it is in Hamlet.

Between these opening and closing glances at humanity's reciprocal relations with the reproductive Earth the images of reproduction are intensely focussed on the principle of spontaneous generation by which ordinary matter becomes alive. Thus, thinking of the death of Fulvia, the rise of Pompey, and his need to return to Rome, Antony remarks: "Much is breeding | Which, like the courser's hair, hath yet but life, I And not a serpent's poison" (1.2.184-6). Lewis Theobald (Shakespeare 1733, 220n8) was the first to gloss this with belief in spontaneous generation evident in Holinshed's description of England:

I might finallie tell you, how that in fennie riuers sides if you cut a turffe, and laie it with the grasse downewards, vpon the earth, in such sort as the water may touch it as it passeth by, you shall haue a brood of eeles, it would seeme a wonder; and yet it is beleeued with no lesse assurance of some, than that an horse haire laid in a pale full of the like water will in short time stirre and become a liuing creature. (Holinshed 1587, U3v, p. 224)

A few minutes later, in the next scene, Antony affirms his belief in such things by swearing "By the fire | That quickens Nilus' slime" (1.3.68-9), which goes directly to the point about what was supposed to be special about the Nile.

In his favourite classical text, Ovid's Metamorphoses, Shakespeare found the following account:

So when the seven-mouthed Nile has receded from the drenched fields and has returned again to its former bed, and the fresh slime has been heated by the sun's rays, farmers as they turn over the lumps of earth find many animate things; and among these some, but now begun, are upon the very verge of life, some are unfinished and lacking in their proper parts, and oft-times in the same body one part is alive and the other still nothing but raw earth. (Ovid 1916a, Book 1 lines 422-29) 
The play is clearly informed by this imagery of the Nile spontaneously generating life, and indeed we might well suppose that the sex-without-generation of the protagonists is somehow related to this generation-without-sex of creatures in the Nile. Thus in an exchange mocking Lepidus's equal love for his fellow triumvirs, Agrippa calls Antony "thou Arabian bird" (3.2.12), meaning the phoenix (OED Arabian a.., bird ‥ . 4a). This implies Antony's singularity (there was only ever one phoenix alive at a time) and hints at his immortality, but most famous of all is the phoenix's asexual reproduction by self-immolation. Enobarbus tops Agrippa's jest with "They [Caesar and Antony] are his shards, and he [Lepidus] their beetle" (3.2.20), which Neill suspects is a glance at Plutarch's account of the asexual reproduction of the scarab or dung beetle (Shakespeare 1994, 3.2.20n).

Antony's pet name for Cleopatra is "my serpent of old Nile" (1.5.25), and indeed her endless transformations--what she calls her "becomings" (1.3.97) that cause Antony to liken her to the shape-shifting Thetis (3.7.60)--could be imaged as the shedding of so many snake-skins. Edward Topsell's follow-up to his history of fourfooted beasts was a history of serpents, in which he recounted the various stories of their spontaneous generation before giving what we would consider the true account of their copulation (Topsell 1608, B3v-B5r). The latter includes a detail that explains how the former came about: the young are hatched from eggs hidden in the ground, which would give the appearance of their arising directly out of the material in which they were buried. Contemporary classifications such as Topsell's treated the crocodile as a kind of serpent, and we might wonder whether Lepidus's drunken enquiry about the nature of the Egyptian crocodile is really an enquiry about Cleopatra herself.

The enquiry occurs in the banquet scene that begins in earnest upon the entry of the triumvirate with Pompey and their respective attendant captains. The triumvirs are mid-conversation:

\section{ANTONY (to Caesar)}

Thus do they, sir: they take the flow o' th' Nile

By certain scales i' th' pyramid. They know

By th' height, the lowness, or the mean, if dearth

Or foison follow. The higher Nilus swells

The more it promises; as it ebbs, the seedsman

Upon the slime and ooze scatters his grain,

And shortly comes to harvest.

LEPIDUS You've strange serpents there?

ANTONY Ay, Lepidus.

LEPIDUS Your serpent of Egypt is bred now of your mud

by the operation of your sun; so is your crocodile.

ANTONY They are so.

(Antony and Cleopatra 2.7.17-28)

The account moves smoothly from plants to animals, from human tending of crops to the spontaneous generation of animals, because the Nile's extraordinary fertility elides the difference between the two. Flooded Egypt itself virtually comes alive. Lepidus wants to know more about these Egyptian serpents: 
LEPIDUS What manner o' thing is your crocodile?

ANTONY It is shaped, sir, like itself, and it is as broad as

it hath breadth. It is just so high as it is, and moves

with it own organs. It lives by that which nourisheth

it, and the elements once out of it, it transmigrates.

LEPIDUS What colour is it of?

ANTONY Of it own colour, too.

LEPIDUS 'Tis a strange serpent.

ANTONY' 'Tis so, and the tears of it are wet.

(Antony and Cleopatra 2.7.40-48)

Antony's tautologous answers give Lepidus nothing, although they have the linguistic form of learned knowledge.

And yet, the point of this exchange might be its very tautological pointlessness. Any attempt to pin down language's meaning necessarily sets off a process of chasing differences, since definition is just a succession of qualifying statements, as the ancient philosophers had noticed. A well-known joke about philosophers extending their definitions to cover new and unexpected cases was told by Diogenes Laertius in an account of his (unrelated) namesake Diogenes the Cynic:

Plato defined man thus: 'Man is a two-footed, featherless animal,' and was much praised for the definition; so Diogenes plucked a cock and brought it into his school, and said 'This is Plato's man.' On which account this addition was made to the definition, 'With broad flat nails.' (Laertius 1891, 231)

The process of refinement is potentially endless, and in general we stop when a sufficient confidence of non-ambiguity has been reached. Coming from Antony and within a play so concerned to contrast the finite and the infinite, tautology is a consumate evasion. To say 'it is what it is' short-circuits the deferral of linguistic gratification, and recalling Julia Kristeva's likening of sexual and linguistic gratification (Kristeva 1984) we might suppose there is also a hint of short-circuiting physical gratification too. As we have seen, Cleopatra is characterized by paradoxical inversions--fans that cool lust and inflame it, food that stimulates appetite as it satisfies it--that gesture at an insatiable desire. The point of this Bacchanalian scene is to show the differing responses of the triumvirs to bodily temptation. Lepidus succumbs to drunkenness while Caesar, painfully aware of his physical susceptibility, exercizes an iron self-control. Antony, whose reputation for excessive indulgence in Egypt raises an expectation of riot, is forearmed with tautology and seemingly inviolable.

Caesar, picking up the sense of gratification, does not think Antony's speech will do: "Will this description satisfy him?" and Antony replies that it will, "With the health that Pompey gives him; else he is a very epicure" (2.7.49-51). Universally ignored and unglossed by editors until the twentieth century, this reference to the philosophy of Epicureanism is cryptic, but John Wilders captures the two main possibilities that it either means Lepidus is "devoted to sensual pleasure" and hence hard to satisfy--the only sense offered by Neill (Shakespeare 1994, 2.7.52n)--or that he really is a follower of Epicurus (371-270 BCE) and hence does not believe in the transmigration of souls (Shakespeare 1995, 2.7.53n). Earlier in the play Pompey had hoped of 
Antony that "Epicurean cooks | [would] Sharpen with cloyless sauce his appetite" (2.1.24-25) so that with corporeal satiety he would be distracted from matters of war. The gluttony invoked is not a matter of quantity but of quality, which is significant because Cleopatra's paradoxical inversions serve to undermine precisely this distinction: the quality of sexual pleasure she gives defers gratification indefinitely, so no amount is enough. In this regard Cleopatra feminizes Antony, making his bounded masculine desire into the boundless feminine desire that contemporary misogynists warned about.

From such a reference to bodily satisfaction we might infer that the play's engagement with Epicureanism is superficial, for the philosophy was considerably more subtle than the simple ideas about bodily pleasure that it has come to stand for in common usage. However, the play's engagement with Epicureanism might also be more subtle than at first appears. Epicureans were proto-Utilitarians in their concern with pleasure above all else, but for them the pleasures of the mind were more important than those of the body and the starting point for mental satisfaction was the elimination (not the exaltation) of bodily wants. Moreover, Epicureanism is a markedly materialist philosophy upon which was based a distinct doctrine of ethics, and it shares Utilitarianism's sense that ethics cannot be grounded in nebulous transcendental categories of good and evil but rather must be based on quantifiable phenomena such as pleasure and pain. It was this that attracted the young Karl Marx to the philosophy, and he wrote his PhD thesis on the differences between the physics of Democritus and Epicurus and their implications for ethics (Marx 1967). Democritus's model of physical interactions was deterministic and allowed no place for chance in the workings of nature, whereas (much preferrably, Marx thought) Epicurus insisted that at the smallest scale interactions had random elements, unpredictable swerves in the movements of atoms, and hence that the universe was not determined. For Marx, Epicurus's view allowed for human freedom: spontaneity and hence human liberty arose from the very nature of matter.

Marx was wrong about this: indeterminism is not logically essential to free will, as the philosopher Daniel Dennett has brilliantly demonstrated (Dennett 2003, 97-139). The play's treatment of how human beings relate to physical nature--explored in relation to the unquantifiable, the insatiable, and the limitlessness of Earthly biology-suggests that Shakespeare, like Marx, took materialism and determinism seriously. As Diogenes Laertius recorded, Epicurus taught a materialist zoology and warned:

Let us also beware of thinking that animals are derived from the infinite; for there is no one who can prove that the germs from which animals are born, and plants, and all the other objects which we contemplate, have been brought from the exterior in such a world, and that this same world would not have been able to produce them of itself. This remark applies particularly to the earth. (Laertius 1891, 451)

Read in this light, Antony's description of the crocodile might be entirely unironic in its denial of external causes. The Earth brings forth peculiar things that arise out of the nature of matter, things that need (indeed, admit) no external explanation but are of their own shape and colour, and are their own cause. For us in the twenty-first century, evolution is the all-embracing theory that--in the teeth of our instinctive demand for reasons--insists that the bare facts of biology admit no reasons. Amongst the seventeenth-century materialists, Isaac Newton stands as the greatest 
because his laws of motion simply bypassed the traditional Aristotelian questions about why things move as they do and confined themselves to describing, almost perfectly, how they move. Fittingly, Newton wished to express his indebtedness to Epicurus in this regard, and there will be more to say about that connection with $\underline{\text { The }}$ Tempest (pp. 00-00 below).

I claimed that Antony's answers to Lepidus are perfectly tautologous, which is not quite true. They contain one positive assertion: that the Egyptian crocodile's soul transmigrates. Wherever else he might have come across this idea of Pythagoras's, Shakespeare undoubtedly found it in Ovid's Metamorphoses. Like spontaneous generation, transmigration of souls denies the special condition of humanity; in poststructuralist terminology it decenters humankind, demoting us to mere containers:

Our souls are deathless, and ever, when they have left their former seat, do they live in new abodes and dwell in the bodies that have received them. . . All things are changing; nothing dies. The spirit wanders, comes now here, now there, and occupies whatever frame it pleases. From beasts it passes into human bodies, and from our bodies into beasts, but never perishes. And, as the pliant wax is stamped with new designs, does not remain as it was before nor keep the same form long, but is still the selfsame wax, so do I teach that the soul is ever the same, though it passes into ever-changing bodies. Therefore, lest your piety be overcome by appetite, I warn you as a seer, do not drive out by impious slaughter what may be kindred souls, and let not life be fed by life. (Ovid 1916b, Book 15 lines 158-175)

To see how twenty-first century science returns us to ancient philosophical questions one only has to substitute 'genes' for 'souls' in the above passage and observe that it remains essentially correct. The new gene-centered perspective raises the unsettling Pythagorean insight that we are merely the vehicles for entities within us that we can scarcely comprehend.

While Antony is aboard Pompey's barge describing Egypt's animals, Cleopatra remains in Egypt receiving information about him. To evoke her African location, Shakespeare has Cleopatra repeatedly refer to the creatures for which it was famous, but this is more than mere dramatic colouring. Railing on the messenger who brings the news of Antony's marriage to Octavia, Cleopatra images the collapse of human society in terms of the transformations of animals:

\section{CLEOPATRA}

Some innocents 'scape not the thunderbolt.

Melt Egypt into Nile, and kindly creatures

Turn all to serpents! Call the slave again.

Though I am mad I will not bite him.

.............

MESSENGER

Should I lie, madam?

CLEOPATRA O, I would thou didst,

So half my Egypt were submerged and made

A cistern for scaled snakes.

(Antony and Cleopatra 2.5.77-96) 
Once things start to go seriously wrong, Cleopatra's rhetoric turns these liquid transformations--"Melt", "submerged", "Dissolve", "discandying"-- upon herself and her family:

\section{[CLEOPATRA]}

From my cold heart let heaven engender hail, And poison it in the source, and the first stone Drop in my neck: as it determines, so Dissolve my life! The next Caesarion smite, Till by degrees the memory of my womb, Together with my brave Egyptians all, By the discandying of this pelleted storm Lie graveless till the flies and gnats of Nile Have buried them for prey! (Antony and Cleopatra 3.13.162-70)

The long final scene of the play, lasting around 20 minutes, is intensely focussed upon the transformation of Cleopatra's body after death. Rather than be shamefully exhibited to the Roman "varletry" by Caesar in triumph, Cleopatra imagines giving herself up to the transformatory creatures of her own country:

[CLEOPATRA] Rather a ditch in Egypt

Be gentle grave unto me; rather on Nilus' mud Lay me stark naked, and let the waterflies Blow me into abhorring;

(Antony and Cleopatra 5.2.56-9)

Neill detects in "gentle grave" a pun on the name of the fly maggots that will enter and transform her body (Shakespeare 1994, 5.2.58n), and if accepted this pun also alludes to fishing, as the OED definition makes clear: "A maggot . . . as employed as bait by angler" (OED gentle $\underline{n}$. 3). Five to ten minutes earlier, Cleopatra herself was angling, for the raising of Antony to the top of her monument in 4.16 put into action an imagined scene of fishing from the middle of the play: "[CLEOPATRA] My bended hook shall pierce | Their slimy jaws, and as I draw them up | I'll think them every one an Antony, | And say 'Ah ha, you're caught!'" (2.5.12-15). For Shakespeare, fishing provided an sharp illustration of death's ironical transformations: as Hamlet put it, "A man may fish with the worm that hath eat of a king, and eat of the fish that hath fed of that worm" (Hamlet 4.3.27-8).

Organic recycling in death is the point of the worm that comes in a basket of food, but to eat rather than be eaten. As Neill notes, Cleopatra's "Will it eat me?" associates this worm with the ones of her grave (Shakespeare 1994, 5.2.270n) and perhaps her final words repeat the pun on the anglers' name for a maggot: "as soft as air, as gentle" (5.2.306). An additional irony, of course, is that this wormy death is itself central to her legend, which endures. The repeated tellings of it (including this one) give a kind of immortality. In that sense, she is indeed as she calls herself "marble-constant" (5.2.236), not merely in sticking to her plan but in becoming legendary: "Not marble nor the gilded monuments | . . shall outlive this powerful rhyme" (Sonnet 55). Her last great speech about Antony memorializes him too ("His legs bestrid the ocean ... His voice ... as rattling thunder" 5.2.81-5), but the 
description is undermined by our last glimpse of Antony falling far short of the hyperbole.

Perhaps sensing that something less exalted might be better, Cleopatra switches to more ordinary comparisons:

\section{[CLEOPATRA] For his bounty,}

There was no winter in 't; an autumn 'twas,

That grew the more by reaping. His delights

Were dolphin-like; they showed his back above

The element they lived in.

(Antony and Cleopatra 5.2.85-9)

The first, agricultural image is even stronger in the Folio text: "For his Bounty, | There was no winter in't. An Anthony it was, That grew the more by reaping" (Shakespeare 1623, zz1r). Emrys Jones defended the Folio reading, noting that, although the logical sense slips in this passage, an audience would have no difficulty understanding the idea of "Antony as a perpetually plenteous harvest" (Shakespeare $1977,5.2 .87 n)$. In fact, that is not quite the idea at stake. Cleopatra makes Antony a paradox of positive feedback like herself: he grows all the more by reaping. Whereas the lesson learnt by Timon of Athens is that things do, eventually, have to add up, here is claimed a contradictory exceeding of all bounds. This insistence upon breaking limits is followed even more aptly with the image of the dolphin, which as Tillyard explained is king of the fishes precisely because it will not remain in its proper element (water) but insists upon raising itself beyond it (Tillyard 1943, 32). As Tillyard rightly commented, the image makes no sense without a model of orderliness and proper place, but equally it achieves its full power by exception from the very rules that give it meaning.

\section{Notes}

${ }^{1}$ In Charles Dickens's David Copperfield, Micawber offers the precept "Annual income twenty pounds, annual expenditure nineteen nineteen six, result happiness. Annual income twenty pounds, annual expenditure twenty pounds ought and six, result misery" (Dickens 1850, 125-26).

${ }^{2}$ Critiquing this association is a central concern of ecofeminist theory and criticism, as exemplified in Branch et al. 1998, Bowerbank 2004, and Phillips 2004. Of the wider concerns of ecofeminism, Mellor 1996, Soper 1996, Kirk 1997 and Nanda 1997 are typical, although it should be understood in relation to the last that the 'green revolution' means the application of science to majority world agriculture in the 1960s.

\section{Works Cited}

Bowerbank, Sylvia. 2004. Speaking for Nature: Women and Ecologies of Early Modern England. Baltimore MD. Johns Hopkins University Press. 
Branch, Michael P., Rochelle Johnson, Daniel Patterson and Scott Slovic, eds. 1998. Reading the Earth: New Directions in the Study of Literature and Environment.

Moscow, ID. University of Idaho Press.

Dennett, Daniel C. 2003. Freedom Evolves. London. Penguin.

Dickens, Charles. 1850. The Personal History of David Copperfield. Illustrations by H. K. Browne. London. Bradbury and Evans.

Holinshed, Raphael. 1587. The First and Second Volumes of the Chronicles. (The Third Volume.) Newlie Augmented and Continued By J. Hooker Alias Vowell Gent. and Others. (A. Fleming; F. Thin [I.e. Thynne; and J. Stow]). STC 13569. Vol. 1. 3 vols. London. [H. Denham,] (at the expenses of J. Harison, G. Bishop, R. Newberie, H. Denham, and T. Woodcock.

Kirk, Gwyn. 1997. "Standing on Solid Ground: A Materialist Ecological Feminism." Material Feminist: A Reader in Class, Difference, and Women's Lives. Edited by Rosemary Hennessy and Chrys Ingraham. New York. Routledge. 345-63.

Kristeva, Julia. 1984. Desire in Language. Oxford. Basil Blackwell.

Laertius, Diogenes. 1891. The Lives and Opinions of Eminent Philosophers. Trans. C. D. Yonge. Bohn's Classical Library. London. George Bell.

Marx, Karl. 1967. "PhD Thesis (University of Jena): 'The Difference between the Democritean and the Epicurean Philosophy of Nature'." Activity in Marx's Philosophy. Edited by Norman D. Livergood. The Hague. Martinus Nijhoff. 57-109.

Mellor, Mary. 1996. "Ecofeminism and Ecosocialism: Dilemmas of Essentialism and Materialism." The Greening of Marxism. Edited by Ted Benton. Democracy and Ecology. New York. Guildford Press. 251-67.

Nanda, Meera. 1997. '"History is What Hurts': A Materialist Feminist Perspective on the Green Revolution and Its Ecofeminist Critics." Material Feminist: A Reader in Class, Difference, and Women's Lives. Edited by Rosemary Hennessy and Chrys Ingraham. New York. Routledge. 364-94.

Ovid. 1916a. Metamorphoses. Trans. Frank Justus Miller. Vol. 1: Books 1-8. 2 vols. The Loeb Classical Library. London. Heinemann.

Ovid. 1916b. Metamorphoses. Trans. Frank Justus Miller. Vol. 2: Books 9-15. 2 vols. The Loeb Classical Library. London. Heinemann.

Phillips, Bill. 2004. "The Rape of Mother Earth in Seventeenth Century English Poetry: An Ecofeminist Interpretation." Atlantis: Revista de la Asociacion Espanola de Estudios Anglo-Norteamericanos 26. 49-60.

Plato. 1871. The Dialogues, Translated in English with Analyses and Introductions.

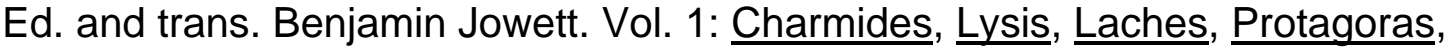


Euthydemus, Ion, Meno, Euthyphro, Apology, Crito, $\underline{\text { Phaedo }}, \underline{\text { Symposium, }}$ Phaedrus, Cratylus. 4 vols. Oxford. Clarendon Press.

Shakespeare, William. 1623. Comedies, Histories and and Tragedies. STC 22273 (F1). London. Isaac and William Jaggard for Edward Blount, John Smethwick, Isaac Jaggard and William Aspley.

Shakespeare, William. 1733. The Works. Ed. Lewis Theobald. Vol. 6: Coriolanus; Julius Caesar; Antony and Cleopatra; Cymbeline. 7 vols. London. A. Bettesworth, C. Hitch, J. Tonson, F. Clay, W. Feales, and R. Wellington.

Shakespeare, William. 1977. Antony and Cleopatra. Ed. Emrys Jones. New Penguin Shakespeare. London. Penguin.

Shakespeare, William. 1994. Anthony and Cleopatra. Ed. Michael Neill. The Oxford Shakespeare. Oxford. Oxford University Press.

Shakespeare, William. 1995. Antony and Cleopatra. Ed. John Wilders. The Arden Shakespeare. London. Routledge.

Soper, Kate. 1996. "Feminism, Ecosocialism, and the Conceptualization of Nature." The Greening of Marxism. Edited by Ted Benton. Democracy and Ecology. New York. Guildford Press. 268-71.

Tillyard, E. M. W. 1943. The Elizabethan World Picture. London. Chatto and Windus. Topsell, Edward. 1608. The Historie of Serpents. STC 24124. London. William Jaggard. 